\title{
LEGAL PRINCIPLES OF ECONOMIC POLICY IN THE ISLAMIC REPUBLIC OF IRAN
}

\author{
Ayoub Ahmadi Gandmani ${ }^{1}$ \\ Mohammad Sadeghi ${ }^{2}$ \\ Babak Baseri $^{3}$
}

\begin{abstract}
In this research, we first describe and explain the terminology and key words used in the title of the research, namely "Legal Basics", "Economic Policy" and "Islamic Republic of Iran". After explaining the terms and key words used in the research title, this question has been raised, what is the legal basis of economic policy in the Islamic Republic of Iran? Given the clarification of the concept of legal principles and other words used in the research title, the answer to this question is in the highest and most valid legal document in the country, the constitution. Our assumption is that the what is the right of the people and the duty of the state is to make policy according to constitutional criteria. Finally, in view of the goals and ideals of the Islamic Revolution of Iran and the post-revolutionary atmosphere of the Islamic Republic, and the Islamic attitudes of the main legislators, which have contributed to the introduction of the constitution and the various principles of the constitution, and ultimately the principles of the constitution in which the use of Islamic economics has been used, has been answered to the question in a descriptiveanalytical method.
\end{abstract} legal basis for economic policy in the Islamic Republic of Iran is Islamic economics, in other words, the main constitutional basis for economic policy,

Keywords: Legal Bases, Constitution, Economic Policy, Islamic Republic of Iran.

the Islamic economy, in other words,

\footnotetext{
${ }^{1}$ Ph.D. Student, Department of Public Law, Bandar Abbas Branch, Islamic Azad University, Bandar Abbas, Iran. Email: rezamashhadi342@yahoo.com.

${ }^{2}$ Assistant Professor, Department of Economic Rights, Hormozgan University, Hormoz Research Center, Hormozgan, Iran. Corresponding Author Email: mrs4272@yahoo.com.

${ }^{3}$ Assistant Professor, Department of Public Law, Shiraz Branch, Islamic Azad University, Shiraz, Iran.Email: baseribabak@gmail.com.
} 


\section{Gênergs}

Introduction

The purpose of this paper is to examine the legal principles of economic policy in the Islamic Republic of Iran. To achieve this, we first describe and explain the terms and key terms used in the title of the article. Because the study of the correct understanding of words and words in any scientific discipline is one of the preconditions for entering this discipline. This issue becomes more valuable in legal studies and, in some respects, it is considered to be literary science, it can be indicative of the position of words and the key role of terminology in the field of law science. It is not undignified in many works of scholars that they see in the beginning of their work, they describe and explain the terms used in that work. ${ }^{4}$

Economics is a phenomenon that the political system of countries, according relying on it takes shape, and it appears to be purely political and governmental. In the process, to determine and stabilize the economic system governing the economies of countries, normally in the constitutions,

${ }^{4}$ Mansour Abadi, Abbas and Riahi, Javad (2012), The Concepts of basic in Legal these include principles that reflect the attitude of the sovereign to the issue of economy and the type of economy that governs each country. By outlining key views on key issues of community economics and avoiding minor and variable issues, they have a very effective role in organizing the economy of any country, commensurate with the attitude adopted by society and its political sovereignty. Chapter Four of the Constitution of the Islamic Republic of Iran, in 13 principles, outlines the general economic principles of society. What in the first conditions of the revolution, more than anything, the atmosphere of the country, because of the anti-colonial nature of the Islamic Revolution of the Iranian people, had been affected, the idea of combating exploitation and colonization, it was the right of the poor and the advantage of the poor over the rich. In creating this atmosphere and creating a negative attitude towards capitalism, two major political and economic factors survived: the exploitation of the country by US and British capitalist regimes and the poor performance of the domestic capitalist.

Research, Journal of Legal Research, No. 22, Second Half Years, Page 10-11 
These issues have made capitalism, in the eyes of the Iranian people, a dark, black spot, and this subconsciously influenced the attitude of representatives of the Assembly of constitution experts. So that, in formulating all the economic principles of the constitution, on the one hand, has tried to the private sector, be restricted and controlled and on the other, the exploitation of others has been severely prohibited. These all indicate the depth of concern and uncertainty about the private sector and private capitalism in those years.

\section{1-The Concept of Legal Basis}

One of the key terms used in this research is the term "legal bases", the term legal principles Despite its plurality of use, there are few definitions of it and the existing definitions are not the same.

Lawyers do not agree on the definition of the legal basis and the expression of its meaning.

Dr. Abbas Mansour Abadi, a faculty member of Tehran University and Javad Riahi, a doctoral student in criminal law and criminology of the

5 .Lewis Malouf "Al-Manjad" (Arabic to Persian), (2007), p. 1, Translator: Mohammad Bandarrygi, Tehran: Iran Publication, Sixth Edition, Pages 7- 106.
University of Tehran, in a research entitled Conceptualism of the foundations in legal research, showed that in the literature and available sources, four meanings for the word The foundations have shown that they are not overlapped, and they represent the fourfold perceptions of the term.

Some writers have called it obligatory force of right and grouping have called it because of credit; some have called them rule of law not specified in the rules, and some have used it as a term to state why a rule of law.

"Basics" literally is a plural for the "base" word that derives from "base".

The word "base" in the Arabic word means building or building a house and also goodness. The word "basics" is also used in the word to buildings or alphabets. ${ }^{5}$

Persian dictionaries have defined the term "basis" as the basis, first, basis and basis. ${ }^{6}$ In English, basics means: "What is supposed to be a comment, belief, etc., the infrastructure element and basic; the starting point;

\footnotetext{
6 .Dehkhoda, Ali Akbar (2010), online
} dictionary: www.loghatname.com 
justification or reason for a subject". Also: "The basic that thing holds on it".

About the terminology of the foundations in legal research it must be said, lawyers who have sought to define the term have not agreed. In the following, the definitions given for the base word are discussed and briefly analyzed and reviewed.

Dr. Nasser Katouzian, in the book Introduction to Law Science and Study in the Iranian Legal System, the phrase "the basis of law" has used in the sense of the binding roots of legal rules. In their view, "the most obvious concept that everyone has of rights and law, is that its rules are imposed on individuals and Creating mandatory. So this question is raised in the minds of any thinker, why should he obey the law? What force is its supportive and what attracts us to enforcing its rules? This force and hidden attraction are called the basis of law ".

Mohammad Jafar Jafari Langroudi, in Volume IV of the book "Extensively in the Terminology of Law," defines the legal basis as follows:

Legal rules that are not explicit or extractable from the rules laid down.

And he discovers the study of the community's interests and the nature of issues and the legal system. In fact, he defines the bases of his rights legal rules that are not explicit or extractable from the rules laid down.

Mahmoud Hekmat Nia the author of the "Foundations of Intellectual Property" in expressing the basic concept said: "The base word, when applied to a rule of legal or legal system, seeks to answer the question of the validity and legitimacy of the rule and the legal system. For example, in the intellectual property system, when we say that the author of the intellectual effect has monopolistic moral and economic rights on the phenomenon of thought, it is questioned why the maker has such rights and what is the origin of the legitimacy of the intellectual property system? The answer to this question may be due to the assumption of a legal rule, or try to give a convincing answer to the question by theoretical and philosophical discussions, or in Islamic law, based on valid sources that indicate the legislator's will, to be presented a valid and applicable reason on intellectual Property. "

Ahmad Haji Deh Abadi, author of the opus of compensation for the loss of the victim at the expense of the state and public institutions in expressing the 
concept of the legal basis, stated that "our understanding of the basis, why is it a rule and a ruling? in a way that ambiguity be overcome and not be no other question to ask.

As it is seen, in the first definition, law is considered as a set of rules of binding, that is, the right to "what is rights" and regardless of a particular legal system or a particular legal entity. Thus, the position of the discussion is much deeper than the level of legal entities and legal systems and is dedicated to the underlying layers of legal issues, which are generally the place of philosophical reflection. ${ }^{7}$

Of course, lawyers and philosophers of law are not unanimous in expressing instances of hidden power and attraction which forces humans to obey the law. Some believe that justice is in the natural of all humans which makes them to obey of legal rules, but in the eyes of others, it is the power of government and state support that forces people to bow against the legal norm. ${ }^{8}$

7 . Mansour Abadi, Abbas and Riahi, Javad (2012), The Concepts of basic in Legal Research, Journal of Legal Research, No. 22, Second Half Years, Page 12

8 . .Katouzin, Naser (2010), Introduction to Law Science and Study in the Legal System however, the author of book "Fundamentals of Law" introduces two principles of Co-operation and justice as a hidden force and latent traction that forces a person to obey the law: "Two types of Correlation, one of The way of similarity in the collective consciousness and the other through the division of social labor, both with each other make the person related and associate on the community Board and make him an integral part of society ... These two types of correlation and spiritual communication of the same principle of co-operation and in addition to the principle of justice are the main issues of the science of law in the present era and in the foundation of the rules and social system. Human rights and duties in communities are derived from these two principles. "

Nonetheless, regardless of the differences in individuals and the implications of the foundations of law, from this point of view, what comes in response to the question "Why is it necessary to obey legal rules?", Is the

of Iran, Tehran: Publication Co., Issue 26, Pages 17 to 20.

9 . Young, Musa (1326), Fundamentals of Law, Volume 1. Tehran: Rainbow, Pages 6 and 7. 
basis of rights that according to various theories can be justice, power The government, the principle of cooperative or non-or all of them.

In defining the basics of law and rules not specified in the rules or rules that are not subject to the rules, the legal foundations are considered to be one of the main features of the basic-the explicit or rules that are not subject to the rules and unfortunately does not explain the very nature of the basics; It seems that this definition can be summed up with the definition that will come after this the definition of the basis for legitimacy and validity.

Defining the legal basis is clearer and more explicit due to credibility and legitimacy, and it gives a measure to achieve a more precise picture of the basis. At the same time, this definition has the particular flexibility that makes the word "foundations" applicable to most levels of legal studies.

For example, if a jurisprudential ruling, such as permit deliberately murder murderer by parents, is questioned for validity reason, what comes in the answer is a narrative of the book and the tradition, and hence the abovementioned doctrines will be the basis of that judgment. Now, if the questioner asks for the validity of the book and the tradition, verbal propositions and assumptions, such as the principle of grace and divine mercy, are answered in response to the foundations or reasons for the validity of the book and the tradition. It is also possible to imagine such a hierarchy in Western law. For example, the reason for the validity of a legal rule can be a majority vote and, at a deeper level, the validity and credibility of the majority vote through the theory of social contract. $^{10}$

Finally about the definition of the basis of why a rule and sentence are also to be said, although this definition attempts to provide a criterion for recognizing the concept of the basis, but is so general and complete that it cannot provide a clear concept of the basis. The objection to this definition is that when a system or a legal rule is followed by the use of "why", a general question is formed which should be crushed by

\footnotetext{
10 . Mansoor Abadi, Abbas and Riahi, Javad (2007), Journal of Research in Law, No. 22, p. 14.
} 
adding another phrase to the more detailed questions. From what has been said, it can be concluded that the definition of the basis is not a precise definition and is not acceptable to what is it a rule and a sentence. In addition, as already explained above, can be folded the definition of the basis to rules not specified in the rules with the definition of the basis for credit and legitimacy reason. Indeed, not specified rules in rules is inside the concept of reasons for valid and justified. Accordingly, if the question of the legitimacy and validity of a rule or legal system is questioned, what can be answered is rules that are not explicitly stated in the law.

On the other hand, each of the definitions of the foundations of law means the binding force of rights and the reason for legitimacy and validity are correct in their place and are acceptable. In other words, the basis is a verbal common for two meanings mentioned, of course, as will be explained in later sections in the term of lawyers, the use of the basis in the second sense is more prevalent so that it can be used to determine the meaning of the base word

11 .Diamond, Nezhad Ali and Shafa'i, Ebadullah (2007), "The Basics of Personal against it, and the meaning of the reason for legitimacy and validity is the true meaning of the base word.

\section{Review of legal works on the basics}

In this section, a number of legal works on the basics of the rules or legal institutions are being studied. The first goal of this review is to show that between the two previously mentioned meanings for the word of the foundation, the meaning of binding force of law and meaning of the reason for the validity second meaning in legal research is more and more widely used and used to a greater extent.

1. The authors of the article on the basis of the personal status of Shiite Afghans $^{11}$ in referring to the origin of legitimacy and the validity of Article 131 of the Constitution of Afghanistan, refer to jurisprudential rules such as the rule of obligation, the principle of tolerance, and the texts of the narrations are cited. From the point of view of Western law, have taken the principles such as justice, legal pluralism, and international human rights instruments on minorities. The authors of the article on the definition

Status of Shiites in Afghanistan," Shi'ite Quotation, Fifth Year, 19 
and principles of openness to criminal procedure have also sought to answer the question "What is the origin of the legitimacy and validity of criminal proceedings?" He responded by stating two grounds for guaranteeing the rights of the accused and ensuring the interests of the community and strengthened by the ideas of lawyers and the provisions of human rights instruments. ${ }^{12}$

The author of generating income on the legal basis of infertility treatment $^{13}$ has sought to justify and prove the legitimacy of infertility treatment. In this regard, he has spoken about the Quran and narratives, and also the ruling of the jurists. The authors of the article on the legislative developments in the propagation of the sacrament and its foundations ${ }^{14}$, like the previous article, have sought to convey the religious propositions and texts of the book and the tradition as the origin of legitimacy and validity of the sacred endowment.

12 .Omidi, Jalil Vanikouei, Somayeh (2008), "The Definition and Foundations of Public Criminal Procedure", Moderator of Humanities, Volume 12, Issue 3

13. Nazari Tavakoli, Saeed (2007), "Income on the Legal Basis of Fertility Therapy", Islamic Studies, 75
As shown in the examples above, as well as the examination of other works, the overwhelming majority of these works sought to answer the question of the credibility and legitimacy of an institution, rule, or legal system. This means that the authors of the works referred to have a concept from the base word which is consistent with the definition of the principles due to the validity and legitimacy. By the above considerations, among the four definitions, only two definitions are justifiable and accepted as independent concepts. It will not be difficult to accept two terms for one word. Because not only in the science of law, but also in other sciences, words that are commonly spoken are of great use. Therefore, the base word is correct in each of the two meanings that is used. From the study of the works in which the term was used, it became clear that in the overwhelming majority of these works, the basis was used in the sense of the cause of legitimacy and validity. In this research,

${ }^{14}$. Anjouinejad, Seyyed Mehdi and Emami, Mohammad (2004), "Legislative changes in the wake of the endowment and its foundations," the moderator of human sciences, period 8,3 
in order to avoid confusion or deviation from the path of research, our meaning and concept of legal foundations is the cause of credibility and legitimacy because individuals and the meanings of each concept differ from persons and examples of another concept, for example when the researcher searches for the foundations A legal entity means the reasons for its credibility his field of study includes the sources of law; while if he seeks the foundations of law as the binding force of law and answers his questions search in the sources of law, such as judicial Procedure and normal and basic Laws, , the path has gone wrong and is diverted from the correct path.

\section{2- Economic policy}

The second term in this study is the term economic policy. Economic debates have a broader scope, including theoretical, legal, scientific and economic policies. Given the wide range of economic issues, it can be divided into the following:

1. Islamic economy: Islamic economy consists of two parts of

\footnotetext{
15 .In the division of economic topics, the
} Book of Income on Islamic Economics has economic law and the school of economics.

In the economic rights debate, are discussed the Islamic law and regulations and its legal effects, and human societies are obliged to execute the orders and leave the bad things and arrange their effects.

The second part of the discussions of Islamic economic is consists of school of economics and represents the main lines of society's values and the goals that society must strive to maintain and achieve.

2- Analytical Economics: The analytical economics consists of the scientific topics of economics and examines the economic behaviors of individuals and builds appropriate patterns in line with school goals and programs.

3- Think economics: Another category of economic topics is about the policies that are adopted in the economic system and are naturally consistent with the data of economics and economic school. ${ }^{15}$

With regard to the above division, the subject of economic policy school and the University be used. 
is a tactic of the economy, which includes the policies used by each economic system. Dr. Asghar Shahmoradi, Faculty Member of the Faculty of Economics of the University of Tehran, in the definition of economic policy, believes that economic policy in a simple definition is to create or apply incentives from the government or other institutions for the purpose of hand Recognizing predetermined goals based on economic policy instruments. In this perspective, the economy is regarded as moving, alert and intelligent, reacting to incentives, and being able to move in the process of gaining feedback and encouraging them to achieve the ultimate goal.

Obviously, economic policy is not looking for a precise plan for achieving goals, but only for directing the economic behaviors of economic agents without directly interacting with their decisions using well-known economic instruments. These tools can be divided into monetary, financial, currency and business tools. An example of monetary instruments, the determination of interbank interest rates, and a sample of financial instruments for government expenditures and tax revenues can be counted. A policy background can be observed in many industrialized countries. These countries have been able to bring about a satisfactory level of prosperity and economic stability for their citizens, believing in the need for economic governance in the form of a policy. Obviously, in these countries, central banks and governments, as policymakers and not planners, work alongside other economic agents who operate and operate on their own merits, regulating relationships and directing affairs.

Economic policy is one of the activities that not only affects the lives of individuals within the national borders, but also the ability to create serious impacts and dramatic changes in regional and international arenas. They bring along. This is especially important in today's world where the interdependence of countries has become more visible than before. For example, a government's economic policy in reducing the level of export of a product that is in the range of its monopoly products, although it may have national economic consequences, is undoubtedly more tangible for global markets. From another perspective, and internationally, economic policies, as a powerful political tool, have an 
irreplaceable position. Economic sanctions are a clear example of the tension between economy and politics.

But on the domestic level, economic policies are worth considering from two perspectives. Firstly, from the perspective of trying to use low-resource sources to create growth and development, and secondly, from the point of view of policy dependence in all areas of education and health to welfare on economic issues and policies in this area. There are few good policies that have been lost due to the inefficiencies of the economic system or policies that are disproportionate to time, place, and subject matter, or have ceased to be in a good cause. Therefore, it is not unreasonable to assert that every aspect of government activities has a economic facade.

What is being studied here is not the entry into the knowledge economy as a specialized branch of human knowledge, and it does not even play a role in introducing economics, but in approaching politics. From a particular point of view, attention is paid to the mainstream of economic policy-

16 . Hamid Reza Malek Mohammadi (1394), Principles of Public Policy, Organization for the Study and Compilation of Human making. Hence, we refer to the reader for more information on the foundations of economics knowledge and its theories to specialized books in this field. ${ }^{16}$

\section{3- Islamic Republic of Iran}

As discussed at the beginning of the discussion, it is essential for the proper understanding of the title of research and the prevention of confusion in the topic. The terminology and vocabulary used in the research title are well explained and explained. Therefore, at the outset, the term legal principles then economic policy Briefly explain the Islamic Republic of Iran.

The Islamic Republic of Iran was the result of a revolution. On February 22, 1979, with the collapse of the monarchy foundation, the Islamic Republic of Iran, under the leadership of the religious and political leadership of Imam Khomeini, came into the realm.

With the victory of the Islamic Revolution in 1979, Iran was flourishing with great changes that were due to the essence of the revolution. Basically, according to the thinkers, the revolution brings with itself changes and changes of

Sciences Books of the University (Tehran), p. 137 
values, structural changes in the social, economic, political and institutional changes and elites, all of which are considered as inevitable consequences of the revolution. In post-revolutionary Iran, the transformation of values became manifold changes in national myths and nationalities, and later became the rule of the revolution, the coupling of religion and politics in the affairs of the country. In the area of structural change, with the collapse of the monarchy, new institutions such as Velayat-e Faqih and the presidency came to the fore, and significant changes in the economic sphere were made, such as looking at the national economy and the government of all financial institutions. In the elite arena, there was a turning point and elite elites were eliminated and revolutionary elites replaced. ${ }^{17}$

The victory of the Islamic Revolution of Iran, which was associated with the massive political participation of the people of Iran, in Iran during the referendum of 1358 confirmed the type of the "Islamic Republic" government for the new political system. The most important step in consolidating the new

17. Wazirian, Amir Hossein and Taleoee, Hadi (2018), Review of the Development Model during the Hashemi Presidency, sovereignty was to approve the constitution, which would distinguish it from the previous regime. This began in July 1358, and by the end of December the laws passed by the Assembly of Experts on the Constitution were adopted by popular vote. With the adoption of the constitution, the supreme leader, headed by the Supreme Leader, who, in accordance with Articles 107 and 109, included a great authority with virtue with political and social insight, was defined at the head of the Islamic Republic's political system. Also, after the Supreme Leader, in accordance with Article 113, the president was recognized as the supreme official and responsible for the implementation of the constitution and the regulation of the relations of the three powers (constitution 1358). However, the president was considered a ritual in the political-administrative structure of the country with all its great titles, and it was the prime minister who was responsible for the executive and the head of the Cabinet of Ministers. This poses a significant challenge between the two executive powers.

Quarterly Journal of Policy, Vol. 4, No. 14, p. 62. 
Iran revolution in the first decade faced major events that affected the orientations of the Islamic Republic as a newly established system in all political, social, economic and cultural spheres. In November 1358, students following the Imam's line by invading the US Embassy hosted their hostages and this caused a sharp reaction from the United States. Although Iran defended its actions. The move that has had the most significant impact on Iran's foreign policy orientation in the years to come, and the United States has faced a confrontation with Iran since then ${ }^{18}$. A year later, in September 1979, the Ba'ath regime of Iraq invaded Iran and imposed an unwanted war on Iran, which lasted eight years. During this period and due to its particular circumstances, all the affairs of the country were overshadowed by the war. Political struggles were defined after the integration of revolutionary sovereignty in 1360 in the circle of the two Islamicrevolutionary left and right factions. In the economic field, the government

18 .Rahamian, Yervand (2010), Modern Iranian History, translated by Mohammad Ebrahim Fattahi, Tehran: Nayan Ney, page 289.

19 .Milani, Mohsen (2004), The formation of the Islamic Revolution and the collapse of chose a government orientation in affairs, and the strategy of nationalizing major industries and banks, controlling prices, paying subsidies, and restricting business policy ${ }^{19}$. Accordingly, the government's policies in the economic field went toward redistribution of wealth in favor of the deprived, and the government imposed control over foreign trade processes, and the privatization and liberalization of the economy were marginalized. In foreign policy, according to the ideals of the Islamic Revolution, and the necessities of a newly established revolutionary state, with domination, domination and anti-Semitism, they moved towards the orientation of neither the East nor the West. Iran's attitude toward this framework was to deal with nations through liberation movements, the development of relations with revolutionary countries, the issuance of revolution and, at the same time, pessimism to international organizations ${ }^{20}$. From the point of view of the nature of the government during

the Pahlavi regime, Tehran, publishing of new Step, p. 363

20 .Dehghani Firoozabadi, Seyed Jalal (2009), Foreign Policy of the Islamic Republic of Iran, Tehran, Publishing of samt, p. 353. 
this period, we encountered a comprehensive ideological rule of the Al-Qawa, in which all the society and the social interests of the people were politically motivated and influenced by the belligerence of the nature of politics. In this regard, the life of the private sphere in all respects was conditional on the will of political power. The domain of government authority in this period, at least in the field of opinion and ideology, did not identify any restrictions, and there was unity and harmony among various political institutions, and all three powers were dominant in the dominant faction ${ }^{21}$.

But with the end of the war and the death of Imam Khomeini, a new situation in the country came about, which was accompanied by a lot of changes. With the election of Ayatollah Ali Khamenei, led by Akbar Hashemi Rafsanjani and based on the presidency of the Islamic Republic, accompanied by structural changes in political power, the country's atmosphere swept through the widespread transformation that clearly distinguished its distinction from the

${ }^{21}$.Bashirieh, Hossein (2002), Preface to the Political Sociology of Iran, Islamic Republic of Iran, Contemporary View, p. 48. earlier period. Gives The economy of the country went through a closed and stateof-the-war era, and in the political arena, the nature of the state, although still stable, had changed, and there was an opening up of the political atmosphere, which was seen in the formation of parties like brokers. In foreign relations, the policy of developing relations with its neighbors and Europe was on the agenda, and Iran began to normalize its relations with the world. In general, the emergence of these changes and economic and political developments in this period was due to the three factors of the end of the war and the need for economic reconstruction, the revision of the constitution and, consequently, the political transformation of the country ${ }^{22}$.

After explaining the terms and key words used in the research title, it should be noted that this research is a legal research that seeks to answer this question, which is the legal basis of economic policy in the Islamic Republic of Iran, which, given the clarification of the concept Legal bases and other key terms used in the title of the article, in

22 .Wazirian, Amir Hossein and Tolouee, Hadi (1396), A Study of the Development Model of Hashemi's Presidency, Policy Discussion, Fourth Year, No. 14, p. 63. 
order to answer this question, we refer to the most authoritative legal document in the country, the constitution, which covers our field of study in this paper. The constitution of each country is an overview of the thoughts, goals and aspirations of the people there, and the covenant that the majority of the people of a nation set to regulate their individual activities on the basis of it; a set of rules and the general rules that define the form of government and the supreme organization of the three powers of the country and their relationship with each other and the rights and freedoms of individuals against the state. In fact, the constitution is at the heart of the political system and the discipline of all affairs, and its strict implementation ensures freedom and human dignity and closes the path to prevent any tyranny, because it is based on the same rule that the state itself Among people, and people also recognize their rights to the state. The constitution is the language of the people's conversation with the authorities; they use the constitution to speak with the people, and people express their expectations in the constitutional language. One of the important issues that has been raised in the constitution of the Islamic Republic of Iran is the economy and finance, which is discussed in chapter four of the constitution, titled "Economics and Finance," in the 13 articles. Now, in accordance with the constitutional principles, especially its economic principles, we seek to answer the above question. Regarding the study of economic policies in various states in the Islamic Republic of Iran and their failure, the examination of the various principles of the Constitution, in particular the principles set forth in chapter four, entitled "Financial and economic policies", shows that politics Economic affairs in the Islamic Republic of Iran, especially the various governments that have come to life during different periods, have not focused on the legal basis of economic policy, and this lack of attention can be one of the reasons for their failure in economic policies. This is where the importance and necessity of explaining the legal basis of economic policy is determined because of what It is important to strictly enforce the constitution, and the best laws, if not executed, are just written on paper. It is hoped that by explaining these bases, economic policy makers in the Islamic Republic of Iran will be governed by the 
constitution of economic policy. Considering the economic principles of the constitution and the fourth chapter of the constitution and Articles 43 and 44 of the constitution, we assume that the legal basis of economic policy in the Islamic Republic of Iran is Islamic economics. Our assumption is that economic policy in the Islamic Republic of Iran should be based on the Islamic economy and that the governments of the Islamic Republic of Iran should put it at the top of their agenda because the will of the constitution is that politics Economic regulation is based on Islamic economic laws. As stated in the previous section, the constitution is the language of the people, and the governments are implementing this law. Therefore, in order to uphold the people's rights and observe the law, economic policy must be based on the constitution.

Regarding the research background, it is clear from the study of the researches carried out. In the field of legal bases of economic policy in the Islamic Republic of Iran, no research has ever been done and lawyers have not entered this area. Most researches by the researchers of economic sciences and political science who have been dealing with economic policy issues with economic and political views. However, research and research related to economic policy can be pointed out as follows:

Sa'idi (1393) In the book on economics and economics in Iran, whose narrative is Dr. Reza Nazmandand of his life, especially the managerial and industrial life throughout the reign of Mohammad Reza Pahlavi, part of it relates to a short but unsurpassed period of domination Technocracy can be noted on the industrial development of Iran in the 1340s. His narratives clarify the uncorrected corners in the history of Iran's industrial development, challenging the result of many researches and challenging many questions and issues. The author states that Techno-gram is not a familiar term in Persian writing about the science of politics and government. But the fact is that in the Pahlavi era, Iran has been dominant in a short time for various reasons and reasons. The historical period in which this book tries to clarify its angles. In this work, Reza niazmand the founder of the Industrial Management Organization and the founder of the Industrial Development and Renovation Organization of Iran, who has played a prominent role in the 
construction of Tabriz Tractor factories, Tabriz Machining, Machine Building and Aluminum Arak during its management in the Industrial Development and Renovation Organization and has also played a valuable role in the creation of the Sarcheshmeh copper industry and Yuriran Company and also at the time of his tenure as a deputy director of the industry at the Ministry of Dr. Ali Ahani, iran national and mak iran Company has been established and started work, as one of the largest economic policy makers in Iran, he has a technical and technical view of economic policy and has never paid attention to legal bases. Another case of economic policy can be mentioned. Economic policy paper is from the perspective of ethics and virtue written by Sayed Hadi Arabi and Hossein Zandi (1396). In this paper, the subject of economic policy is from Moral and virtuous perspectives The authors of this work state that economic policy is essentially based on a kind of ethical approach that determines the purpose and direction of that policy. In conventional economics, the utilitarian approach forms the basis of the ethics of politics. In philosophy of ethics, utilitarianism has other contenders, including virtue, whose policy implications have different consequences for them. In this paper, Virtueism is considered as an alternative to utilitarianism in economic policy and it is discussed how this ethical approach can, in the context of utilitarianism, play a role and influence on politics. Another relevant record that can be found in the research is the article on the analytical and functional analysis of economic policy processes written by Abbas Mosallanejad (2011), which states that this paper is also a political and economic approach, not legal, for paid to economic policy issues.

Researches and other articles are also titled on the study of the effect of economic policies on the bilateral costs of Iran, the study of the factors of economic policies affecting the mental health index in this field and .... . As it is seen in the research background, about economic policy, books and articles have been written that are often discussed from an economic and political point of view, However, no research has ever been done on the legal principles of economic policy in the Islamic Republic of Iran.

This research is an applied research that will be done in a 
descriptive-analytical Method and way to compile the content, is reviewing documents (library).

\section{The Constitutional Basis for}

\section{Economic Policy}

In the first years of the revolution, the atmosphere of the country was most affected by the anti-colonial nature of the Islamic Revolution of Iran, the idea of struggle against colonialism and exploitation, and the recognition of the rights of dignitaries and the superiority of the caliphs over the palaces. Under the influence of this revolutionary and Islamic perspective, the main legislator has legislated and, in various principles, especially Articles 43 and 44, and Chapter Four of the Constitution, in the Thirteen Principles, has designed the principles and policies of the general society of society and has set criteria for it.

Since in the legal documents, the introduction, it is the subject of the introduction of the subject, the fields of formation, the mission and purpose of the document. One of the requirements

23 .Kabī, Abbas, Asghari Shoorastani, Mohammad Reza and Asl Zaem, Amir Hossein (1393), The role of the constitutional introduction in interpreting for providing an accurate interpretation of a legal document is the attention to its introduction. The constitution of the Islamic Republic of Iran is not excluded from this general rule and it is necessary for its introduction to provide a proper interpretation of it, which expresses the principles governing the provisions contained in the text of the constitution and as its components and foundations Is attention $^{23}$. In the introduction to the constitution of the Islamic Republic of Iran, the constitution of the Islamic Republic of Iran reflects the cultural, social, political and economic institutions of the Iranian society based on Islamic principles and standards that reflect the heart of the Islamic ummat. It goes on to state that the fundamental characteristic of this revolution is that of other Islamic movements in Iran during the recent centuries, and it states elsewhere that the mode of government in Islam arose from a class position and domination It is not an individual or a group, but a crystallization of the political aspiration of a nation, both selforganization and organization, to

the principles and understanding of the goals and objectives of the constitution of the Islamic Republic of Iran, Journal of Legal Sciences, Vol. 3, No. 10. 
organize itself in an intellectual and ideological way to reach the ultimate goal of moving towards Allah. With regard to the introduction of the constitution, it seems that the mission of the constitution of the community is based on Islamic positions, intellectual positions and genuine Islamic worldview. And guaranteeing the rejection of any intellectual and social tyranny and economic monopoly.

In the introduction to the constitution of the Islamic Republic of Iran, they consider legislation as referring to the circuit of the Qur'an and the Sunnah, and it is necessary and absolutely necessary to closely monitor and monitor the area of the righteous and righteous Islamic scholars. The introduction of the constitution of the Islamic Republic of Iran introduces the economy as a means, not the goal, and states that in consolidating the economic foundations of the principle, the needs of human beings are in the course of its development and development, not as other economic systems are multiplicative Profit and wealth, because in the material schools, the goal of the economy is itself, and thus in the stages of growth, the economy is the cause of destruction and corruption, but in Islam it is a means of economics, and it is not expected by the expected means of better performance in reaching the goal. It could be. With this view, the Islamic economics program provides a suitable basis for the development of different human creations, and therefore the duty of the Islamic state is to provide equal and appropriate facilities and to create work for all individuals and to meet the necessary needs for the continuation of the its evolutionary movement.

In clause 12 of Article 3 of the Constitution, the Government of the Islamic Republic is obliged to use all its facilities to establish a just and fair economy in accordance with Islamic norms.

In Article 44 of the Constitution, the economic system of the Islamic Republic of Iran is based on three parts: public, cooperative and private. After explaining the public sector, the cooperative sector includes companies and cooperative enterprises that produce and distribute in the city and The village is formed according to Islamic rules.

As we can see, in the preamble of the constitution, which indicates the mission and purpose of the constitution, it is in the Islamic constitution, in paragraph 12 of the third principle, of the 
correct and just economy, in accordance with Islamic norms, and, in principle, forty four as the most important and The most basic economic principle of the constitution has been applied to the Islamic Republic of Iran's economic system in accordance with Islamic criteria. Given the above, it is clear. The basis of the constitution for economic policy is based on the Islamic economy.

\section{Conclusion}

Considering the goals and ideals of economic the Islamic Revolution of Iran and the constitution that majority of the Muslim people of Iran; ending the looting of Beit Elmal by the Pahlavi dynasty and royal regime officials; protecting underground reserves and mines; striving for technological progress, independence and self-sufficiency Economic selfsufficiency, providing self-sufficiency in science and technology, establishing a just and fair economy, striving for eradicating poverty and deprivation, providing people with basic needs, providing conditions for employment, regulating the country's economic program in a way that enhances the selfimprovement and enhance the skills and initiative of individuals Society, preventing exploitation and exploitation, prohibiting harm to Monopoly, hoarding and riot, the prohibition of lavishness and attachment, the prevention of foreign economic domination over the country's economy, the attempts to increase agricultural and industrial production, the move towards economic justice and the reduction of class distance, the treatment of the villages of the country and the deprivation of them, The prosperity and pride of the country, in the light of the realization of the values and principles of the pure Mohammadi Islam (PBUH). As well as the Islamic views of the main legislators in the Islamic Republic of Iran and the insertion of Islamic economics into the preamble of the constitution and economy, according to Islamic norms, in paragraph 12 of the third principle of the constitution, as well as in accordance with Islamic law in Article 44 of the constitution and the rule of law In view of the fact that the constitution of the Islamic Republic of Iran is a school law which is based on the school of Islam and the teachings of Islam, it can be concluded that the basis of the constitution of the Islamic Republic of Iran for economic policy is the Islamic economy, and since the law The essential thing is to talk and prove it 
Economic policy-making based on Islamic economics suggests that in the Islamic Republic of Iran, economic policies are credible and legitimate in accordance with the Islamic economy and Islamic standards and economic policies that meet the criteria and criteria of the economy Islam and Islamic standards are not credible and legitimate. In addition, according binding of the constitution, economic policy makers in the Islamic Republic of Iran must regulate their economic policies in accordance with the Islamic economy and Islamic policy. in Islamic Republic of Iran according to the constitution, politician or economic policy makers who are they or who is it? what is the Islamic economy? What are the norms and criteria of the constitution for Islamic economics? It requires another article that the author will write at a later time.

\section{Sources and References}

Arabic, Hadi and Zandi, Hussein (2018), Economic Policy in Ethics and Virtue, Quarterly Journal of Humanities Methodology, No. 90.
Ashtarian, Kiyomars (2014), Policy

Sciences and its achievements for Iran, Research Institute for Humanities and Cultural Studies.

Bidabad, Bijan (1998), Modeling of Iran's Economy, Tehran, Central Bank of the Islamic Republic of Iran.

Branson, William H. (1999), Theory and Major Economics, translation by Abbas Shakeri, Tehran, publication.

Butler, Immun (1999), Economic Thoughts of Milton Friedman, Translation by Fereidoun Tafazlini, Tehran, Publishing.

Deen, Hartley (2009), Social Policy, Translation by Abdullah Bejranlou, Research Institute for Cultural and Social Studies.

Gholipour, Rahmatullah and Faghihi, Mehdi (2015), Public Policy Policies and Analysis, Mahkame Publications.

Khanbashi, Mohammad (2011), The Effect of Social Factors on the Level of Political Trust, Research Institute of Humanities and Cultural Studies, Strategic Quarterly, No. 61. 
Khoshadurian, Edmund and Kheybani, Naser (2001), The Design of a Great Model of Econometric Economics for Policymakers in Iran's Economy, Tehran, Peigan Publishing.

Maslanejad, Abbas (2008), Basics of Economics and Politics, Tehran, Sharif.

Mirkhshan, Masoud and Mehraara, Mohsen (2004), "A Look at Iran's Economy", Islamic Republic Publications, Research Center.

Mosalli Nejad, Abbas (2012), Economic Policy and Social Responsibilities of the Government, Quarterly Journal of Policy, Volume 42, Issue 1.

Mottaki, Ibrahim and Javid, Mehdi (2011), Economic Policy in the Age of Economic Globalization, Quarterly Journal of Policy, Volume 41, Issue 2.

Pejouyan, Jamshid (2006), as a Necessity for Economic Development, towards the Policy and Economic Policy Structure, Yas's Strategy, Second Year, No. 6.
Sa'idi, Ali Asghar (2018), "Technocracy and Economic Policy in Iran" by Reza Nazemand, The Thought publishing.

Shakeri, Abbas and Mohammadi, Timur (2007), Economic Policy Plans for Development, Economic Research, Volume 7, Issue 1.

Vahid, Majid (2004), General policy making, publication of rates 